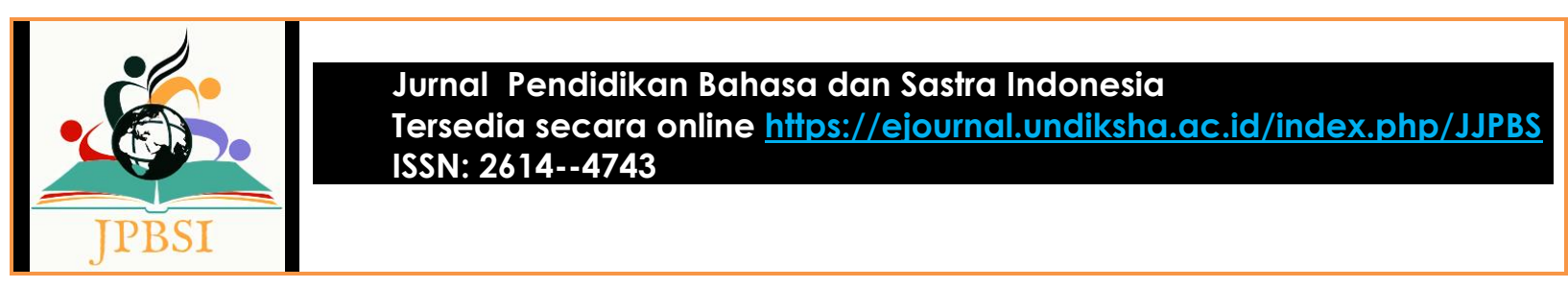

\title{
ANALISIS TOKOH UTAMA PADA NASKAH DRAMA CERMIN KARYA NANO RIANTIARNO DENGAN PENDEKATAN ESKPRESIF
}

\author{
Nadiva Salsabila ${ }^{1}$, Wika Soviana Devi ${ }^{2}$ \\ ${ }^{1,2}$ Program Studi Pendidikan Bahasa dan Sastra Indonesia, Universitas Muhammadiyah Jakarta \\ Ciputat, Jakarta Selatan, Indonesia
}

Surel: $\underline{\text { nadivasalsa90@gmail.com }}{ }^{1}$, wikasoviana@umj.ac.id $^{2}$

\begin{tabular}{|c|c|}
\hline \multicolumn{2}{|r|}{ Abstrak } \\
\hline $\begin{array}{l}\text { Kata Kunci: Naskah } \\
\text { Drama; Pendekatan } \\
\text { Ekspresif; Tokoh } \\
\text { Utama. }\end{array}$ & $\begin{array}{l}\text { Penelitian ini bertujuan untuk mengkaji tokoh utama yang terdapat dalam naskah } \\
\text { drama "Cermin" karya Nano Riantiarno berdasarkan ekspresi atau ide pengarang itu } \\
\text { sendiri. Pada sebuah karya sastra tentu saja seorang penulis akan menuangkan segala } \\
\text { idenya sebagai produk imajinasi yang dimiliki. Hal ini berpengaruh terhadap unsur- } \\
\text { unsur yang membangun cerita itu sendiri. Salah satunya ialah tokoh utama pada } \\
\text { sebuah karya sastra khususnya naskah drama. Tokoh dalam naskah drama merupakan } \\
\text { unsur penggerak dalam cerita. Drama yang berjudul "Cermin" karya Nano Rintiarno } \\
\text { ini memiliki tokoh utama yang unik untuk dikaji. Adapun pendekatan yang digunakan } \\
\text { untuk melakukan analisis ialah dengan pendekatan ekspresif. Pendekatan ekspresif } \\
\text { merupakan pendekatan yang mengkaji ekspresi perasaan atau temperamen penulis. } \\
\text { Hanya terdapat satu tokoh yang berperan aktif dan merangkap tokoh-tokoh lain } \\
\text { berdasarkan apa yang ia bayangkan layaknya sebuah cermin. Pola cerita seperti ini } \\
\text { tentu saja merupakan buah dari pemikiran penulis. Adapun metode yang digunakan } \\
\text { dalam menganalisis naskah drama ialah metode kualitatif deskriptif. Data pada } \\
\text { penelitian ini ialah berupa kutipan-kutipan dialog dalam naskah drama "Cermin" } \\
\text { karya Nano Riantiarno. Data diperoleh dengan membaca secara cermat dan mencatat. } \\
\text { Hasil analisis tokoh utama pada naskah drama "Cermin" dalam penelitian ini } \\
\text { dilakukan dengan tiga langkah sebagai berikut. 1. Biografi Nano Riantiarno, } 2 . \\
\text { Penafsiran pemahaman drama melalui unsur-unsur pembangunnya, 3. Kajian } \\
\text { berdasarkan tinjaun psikologis/kejiwaan pengarang. }\end{array}$ \\
\hline \multicolumn{2}{|r|}{ Abstract } \\
\hline $\begin{array}{l}\text { Keywords: } \\
\text { Play Script; } \\
\text { Expressive Approach; } \\
\text { The Main Character. }\end{array}$ & $\begin{array}{l}\text { This study aims to examine the main character contained in the drama script "Mirror" } \\
\text { by Nano Riantiarno based on the expression or idea of the author himself. In a } \\
\text { literary work, of course, a writer will pour all his ideas as a product of his } \\
\text { imagination. This affects the elements that make up the story itself. One of them is the } \\
\text { main character in a literary work, especially a drama script. The characters in the } \\
\text { drama script are the driving elements in the story. The drama, entitled "Mirror" by } \\
\text { Nano Rintiarno, has a unique main character to study. The approach used to perform } \\
\text { the analysis is an expressive approach. The expressive approach is an approach that } \\
\text { examines the expression of the author's feelings or temperament. There is only one } \\
\text { character who plays an active role and doubles as other characters based on what he } \\
\text { imagines like a mirror. The pattern of stories like this is of course the fruit of the } \\
\text { author's thoughts. The method used in analyzing the drama script is descriptive } \\
\text { qualitative method. The data in this study are in the form of dialogue quotes in the } \\
\text { drama script "Mirror" by Nano Riantiarno. Data obtained by reading carefully and } \\
\text { taking notes. The results of the analysis of the main character in the "Mirror" drama } \\
\text { script in this study were carried out in three steps as follows: 1. Nano Riantiarno's } \\
\text { biography, 2. Interpretation of drama understanding through its building elements, } 3 . \\
\text { A study based on the author's psychological/psychological review. }\end{array}$ \\
\hline $\begin{array}{l}\text { Diterima/direview/ } \\
\text { dipublikasi }\end{array}$ & 26 Juni 2021/ 12 Juli 2021/ 30 September 2021 \\
\hline
\end{tabular}




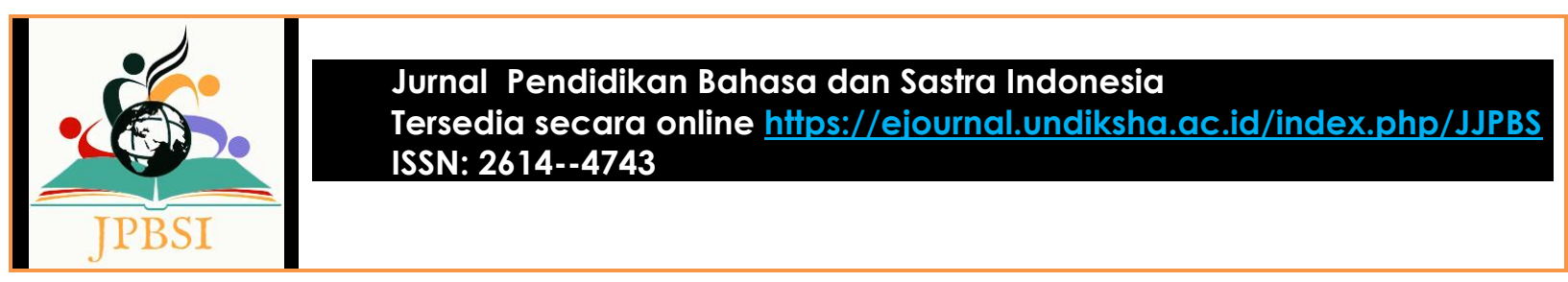

\section{PENDAHULUAN}

Karya sastra merupakan hasil dari daya cipta, karsa manusia yang mengandung nilai seni yang tinggi. Dalam penciptaan karya sastra, seorang penyair tidak menciptakannya secara asal-asalan. Melainkan membutuhkan usaha yang keras untuk bisa menghasilkan sebuah karya yang bermutu. Selain itu, banyak aspek yang dapat dipertimbangkan dalam pembuatan sebuah karya sastra. Misalnya aspek keindahan, nilai guna atau manfaat. Keindahan menimbulkan rasa senang bagi orang yang melihat atau mendengarnya. Akibatnya banyak waktu yang diperlukan penyair atau pengarang dalam membuat karya sastra tersebut. Salah satu karya sastra yang dapat dinikmati keindahannya ialah drama. Dalam Kamus Besar Bahasa Indonesia (KBBI), terdapat beberapa pengertian drama. Pertama, drama diartikan sebagai komposisi syair atau prosa yang diharapkan dapat menggambarkan kehidupan atau watak melalui tingkah laku atau dialog yang dipentaskan.

Kedua, ialah sebagai cerita atau kisah terutama yang melibatkan konflik atau emosi, yang khusus disusun untuk pertunjukan teater. Ketiga, kejadian yang menyedihkan. Sedangkan menurut Budianta dkk (2002), drama merupakan genre sastra yang menunjukan penampilan fisik secara lisan setiap percakapan atau dialog antara pemimpin di sana. Pada drama terdapat kesenian yang menggambarkan sifat dan sikap manusia dengan gerak. Melalui hal tersebut, akan membantu penonton dalam memahami isi cerita. Tujuan mempelajari drama adalah memahami tokoh yang diperankan sebaik-baiknya dalam sebuah pementasan. Drama merupakan genre karya sastra yang menggambarkan kehidupan manusia dengan gerak. Drama menggambarkan realita kehidupan, watak, serta tingkah laku manusia melalui peran dan dialog yang dipentaskan. Sebagai salah satu genre sastra, drama memiliki kekhasan dibandingkan dengan genre lain yaitu puisi dan fiksi.

Drama memiliki kekhasan dari sudut pemakaian bahasa dan penyampaian amanatnya. Pemaparan bahasa yang digunakan dalam sebuah drama berupa pemakaian petunjuk lakuan yang menggambarkan suasana dan penggunaan dialog para tokoh. Menurut Nurgiyantoro dalam Suroso (2015), drama sebagai karya sastra secara struktural memiliki elemen tokoh, jalan cerita, latar, tema, dan amanat. Persoalan yang dimunculkan pada sebuah naskah drama biasanya merupakan penggambaran dari realita kehidupan. Mulai dari persoalan politik, sosial, maupun budaya yang dialami oleh pengarangnya. Pesan yang disampaikan penulis naskah drama terhadap kehidupan bertujuan untuk memberi informasi, mendidik, memberi hiburan, sekaligus mengkritik persoalan yang terjadi di masyarakat.

Adapun struktur drama menurut Waluyo dalam Suroso (2015) terdiri atas penokohan dan perwatakan, plot atau kerangka, dialog atau percakapan, setting/landasan/tempat kejadian, tema/ nada dasar cerita, amanat, petunjuk teknis, dan drama sebagai interpretasi kehidupan. Jika dipilah dalam struktur batin dan struktur fisik, struktur fisiknya berupa tokoh, alur, latar, dialog, dan teks samping. Sedangkan struktur batinnya adalah tema, dan amanat. Pada sebuah drama yang menjadi ikon ialah dialog yang akan dimainkan oleh para tokohnya. Tokoh atau penokohan merupakan salah satu unsur penting dalam sebuah drama. Ia berperan untuk membangun cerita agar terlihat nyata atau hidup. Biasanya, para tokoh akan diperankan sesuai dengan teks naskah drama yang ada. Tetapi ada juga yang menggunakan cara dengan melakukan improvisasi.

Menurut Nurgiyantoro (dalam Riani dkk, 2016), istilah tokoh menunjuk pada orangnya, pelaku cerita, misalnya sebagai penjawab terhadap pertanyaan: siapakah tokoh utama pada naskah drama tersebut? Atau ada berapa jumlah orang pelaku dalam naskah drama tersebut? Atau siapakah yang menjadi tokoh utama dalam naskah drama tersebut? Dan sebagainya. Penokohan sendiri merupakan pelukisan gambaran yang jelas tentang seseorang yang ditampilkan dalam sebuah cerita. Penokohan dan karakterisasi-karakterisasi sering juga disamakan artinya dengan karakter dan perwatakan yang menunjuk pada penempatan tokoh-tokoh tertentu dengan watak-watak tertentu dalam sebuah cerita naskah drama. Menurut Khairil (2010) tokoh ialah pelaku dalam karya sastra. 


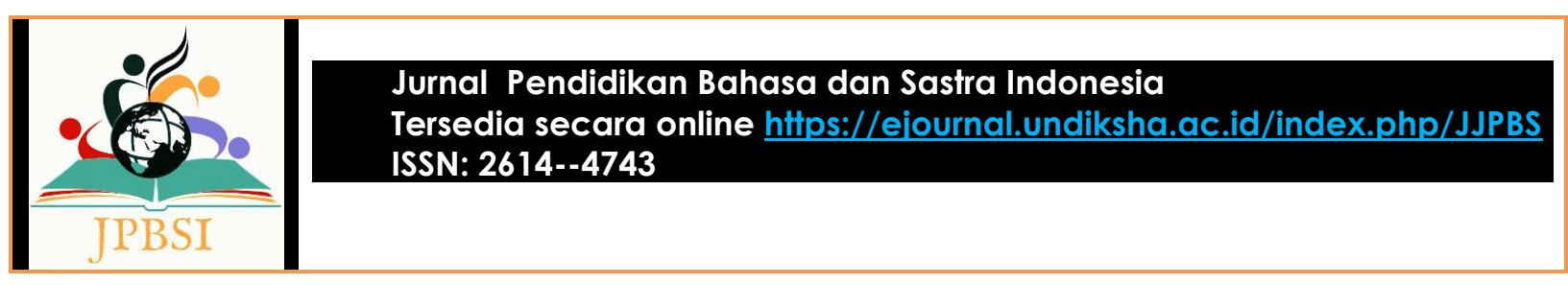

Adanya tokoh dalam sebuah cerita berperan sangat penting untuk menghidupkan suasana dan menggambarkan bagaimana jalan cerita yang dibuat oleh pengarang.

Tokoh dalam cerita memiliki varian fungsi atau peran, mulai dari peran utama, penting, agak penting, sampai sekadar penggembira saja. Perbedaan peran inilah yang menjadikan tokoh mendapat predikat sebagai tokoh utama (sentral), tokoh protagonis, antagonis, peran pembantu utama (tokoh andalan), tokoh tidak penting (figuran), dan tokoh penggembira (lataran). Berdasarkan peranannya dalam sebuah cerita drama, tokoh utama merupakan tokoh yang diutamakan penceritaannya dalam cerita drama yang bersangkutan. Tokoh yang dikemukakan pun, tidak akan begitu saja secara serta merta hadir kepada pembaca. Melainkan, perlu adanya sarana yang mendukung kehadirannya sesuai dengan tujuan yang artistik karya yang bersangkutan. Sama seperti yang akan dibahas pada analisis teks drama "Cermin" karya Nano Riantiarno. Didalamnya terdapat tokoh yang digambarkan pengarang sebagai seorang laki-laki yang malang.

Dikatakan malang karena banyak sekali kejadian tak mengenakan dan membuat dirinya menyesal sekaligus puas atas apa yang ia lakukan. Sebagai seorang pembaca, hal pertama yang akan ditanyakan ialah bagaimana bisa. Dalam naskah drama yang dibuat oleh Nano Riantiarno ini, terdapat beberapa tokoh. Namun, tidak digambarkan secara langsung oleh pengarang, melainkan digambarkan secara tersirat melalui tokoh utama si "Laki-Laki" dengan bentuk dialog atau kata yang diucapkan olehnya. Tentu saja, hal ini membuat para pembaca merasa heran dan cerita pun menjadi lebih menarik. Dikatakan demikian karena tokoh utama laki-laki ini seperti memegang semua peranan yang terdapat pada cerita drama, sesuai dengan judul yang dibuat oleh si pengarang yakni "Cermin". Untuk memahami lebih dalam terkait tokoh utama pada naskah drama, diperlukannya kajian analisis melalui pendekatan-pendekatan dibidangnya.

Pembuatan karya sastra tentu tidak lepas dari peran seorang pengarang di dalamnya. Dalam penciptaannya pun, tidak secara asal-asalan. Melainkan membutuhkan usaha yang keras dan beberapa aspek yang akan dipertimbangkan nantinya. Misalnya aspek keindahan, nilai guna atau manfaat, aspek psikologi, dan lain sebagainya. Akibatnya banyak waktu yang diperlukan seorang pengarang dalam membuat suatu karya sastra. Salah satu kegiatan yang dapat dilakukan untuk menikmati sebuah karya sastra ialah dengan mengapresiasinya melalui sebuah analisis. Tentu saja dalam menganalisis sebuah karya sastra harus menggunakan metode atau cara yang tepat. Agar apa yang ingin disampaikan oleh pengarang dapat diterima kepada pembaca atau penikmat karya sastranya. Salah satu kegiatan analisis yang dilakukan ialah dengan menggunakan pendekatan ekspresif. Menurut Abrams (dalam Sugiarto, 2010) pendekatan ekspresif merupakan pendekatan yang mengkaji perasaan atau tempramen penulis.

Sedangkan menurut Semi (dalam Sugiarto, 2010) pendekatan ekspresif adalah pendekatan yang menitikberatkan perhatian kepada upaya pengarang atau penyair mengekspresikan ide-idenya ke dalam karya sastra. Dari pengertian tersebut dapat kita artikan bahwa pendekatan ekspresif sangatlah berkaitan dengan latar belakang si pengarang itu sendiri. Selain itu, dalam melakukan analisis pendekatan ekspresif ini berkaitan dengan unsur-unsur pembangun karya sastra itu sendiri. Seperti latar atau setting, tema, tokoh dan penokohan, plot atau alur, dan lain-lain. Tidak hanya itu saja, dalam penelitian melalui pendekatan ekspresif, ada tiga hal utama yang harus dituliskan; seperti biografi pengarang, penafsiran pemahaman drama, dan kajian berdasarkan tinjauan psikologis atau kejiwaan pengarang. Hal inilah yang melatar belakangi adanya penelitian untuk mencari tahu seperti apa ide atau ekspresi penulis (Nano Riantiarno) yang ingin dituangkan lewat tokoh utama pada cerita yang ia buat. 


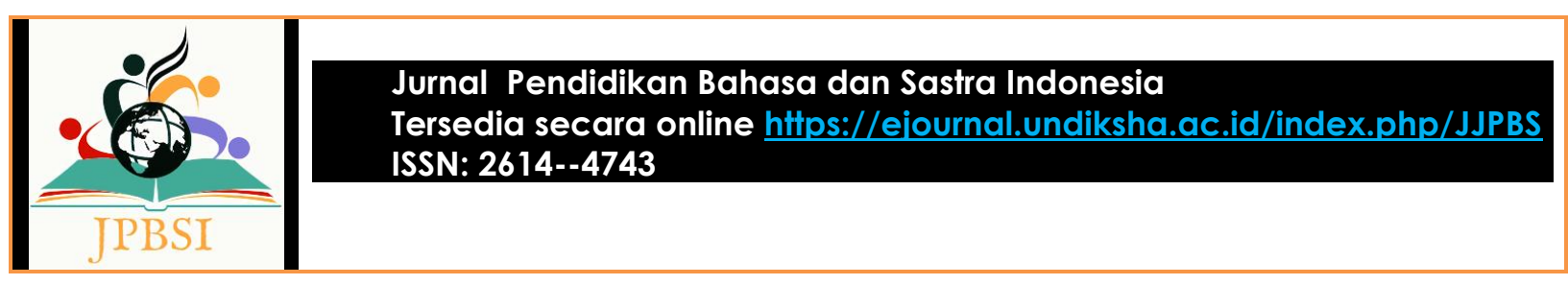

\section{METODE PENELITIAN}

Pendekatan yang digunakan dalam penelitian tokoh utama pada novel "Cermin" karya Nano Riantiarno ialah dengan menggunakan pendekatan deskriptif kualitatif. Dikatakan deskriptif kualitatif karena peneliti akan mendeskripsikan data yang dianalisis berupa unsur intrinsik khususnya tokoh utama melalui pendekatan ekspresif. Adapun data yang akan digunakan ialah sebuah teks naskah drama yang berjudul "Cermin" karya Nano Riantiarno. Dari teks naskah drama tersebut, peneliti akan membaca secara cermat dan melakukan pencatatan terkait dengan pembahasan yang akan dianalisis. Selanjutnya ialah mencari sumber referensi melalui jurnal-jurnal penelitian terdahulu yang terkait dengan pendekatan ekspresif itu sendiri. Terdapat tiga langkah dalam melakukan pembahasan terhadap kajian yang diteliti. Yakni mengenai biografi pengarang, penafsiran pemahaman drama, dan kajian berdasarkan tinjauan psikologis atau kejiwaan pengarang. Langkah pertama ialah mengetahui biografi dari Nano Riantiarno. Dikatakan demikian, karena pendekatan ini merupakan pendekatan yang mengaitkan sebuah karya sastra dengan pengarangnya. Maka, langkah pertama dalam menerapkannya ialah dengan mengenal biografi pengarang karya sastra yang akan dikaji. Langkah kedua ialah dengan melakukan penafsiran pemahaman unsur-unsur yang terdapat dalam teks drama. Seperti tema, alur/plot, latar/setting, tokoh, dan lain-lain. Langkah ketiga yang akan dilakukan ialah dengan mengaitkan hasil penafsiran berdasarkan tinjauan psikologis pengarang. Hal ini dikarenakan produk atau tokoh utama yang akan diteliti merupakan bentuk dari pemikiran, ide, dan ekspresi pengarang yang berada pada situasi setengah sadar, setelah jelas baru dituangkan secara sadar.

\section{HASIL DAN PEMBAHASAN}

Penelitian ini menggunakan teori ekspresif yang dikemukakan oleh Abrams sebagai sebuah teori yang memandang karya sastra terutama sebagai pernyataan atau ekspresi dunia batin pengarang selaku pencipta karya sastra. Yang mana karya sastra dipandang sebagai sarana pengungkapan ide, angan-angan, cita-cita, pikiran, dan pengalaman pengarang. Teori yang digunakan untuk mengetahui bagaimana ekspresi pengarang melalui tokoh 'Aku' pada naskah drama yang telah dibuatnya. Oleh karena itu, peneliti menganalisis tokoh utama pada naskah drama 'Cermin' dengan pendekatan ekspresif. Berikut akan peneliti uraikan tiga langkah sebagai hasil dan pembahasan dari analisis tokoh utama pada naskah drama "Cermin" karya Nano Riantiarno melalui pendekatan ekspresif.

\section{Biografi Pengarang}

Nobertus Riantiarno atau yang lebih sering dikenal dengan Nano Riantiarno merupakan seorang aktor, tokoh teater penulis, sutradara dan wartawan Indonesia. Pria kelahiran Cirebon, 6 Juni tahun 1949 ini juga dikenal sebagai suami dari aktris Ratna Riantiarno. Setelah lulus SMA, Nano melanjutkan sekolah teater di Akademi Teater Nasional Indonesia. Aktif dalam perkumpulan teater semenjak masa kuliah, telah membawa nama Nano ke berbagai pementasan teater di Jakarta. Sebagian besar karya panggungya pun ia tuliskan sendiri seperti Rumah Kertas, Maaf.Maaf.Maaf, Opera Sembelit, Sampek Engtay, dan masih banyak lagi. Pada tahun 1977 ia bersama pekerja teater lainnya seperti Rima Melati, Titi Qadarsih, Ratna Madjid, Jajang Pamontjak mendirikan Teater Koma. Bersama Teater Koma, ia telah menggelar 111 produksi panggung dan televisi. Pada tahun 1975, Nano mendapat kesempatan untuk berkeliling Indonesia mengamati teater rakyat dan kesenian tradisional. Tahun 1985, Nano menjabat sebagai ketua Komite Teater Dewan Kesenian Jakarta, Anggota, Komite Artustik Seni Pentas untuk kesenian Indonesia di Amerika Serikat. Selain menuliskan naskah untuk pementasan teater, Nano juga menulis skenario film dan televisi. Salah satu naskah yang ia tulis, JAKARTA, JAKARTA berhasil menyabet Piala Citra pada FFI tahun 1978 di Ujung Pandang. Pada tahun 1979, Nano mendirikan majalah zaman dan berkerja sebagai redaktur. Ia juga mendirikan majalah Matra pada tahun 1986 dan menjabat sebagai Pemred. 


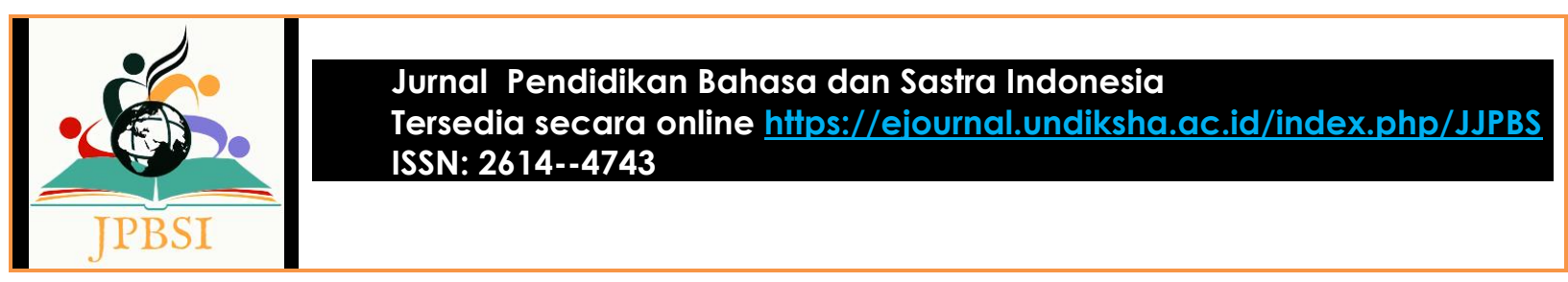

\section{Penafsiran Pemahaman Drama}

Tema Drama "Cermin" ini menceritakan atau membahas kehidupan dari segi asmara, sosial, moral, dan juga agama. Tema yang terkandung dalam drama ini yaitu; "Kisah cinta yang dibalut dalam sebuah pernikahan namun tidak ada kebahagiaan di dalamnya melainkan penuh kekecewaan dan penyesalan yang tak berujung."

Tempat: Di dalam penjara, hal ini dibuktikan dengan penggambaran yang dilakukan langsung oleh pengarang. Terdapat dalam paragraf ketiga baris kedua: "Dalam penjara seorang laki-laki kirakira berumur 35 tahun kaget ketika sadar bahwa dia sekarang berada dalam terang."

Suasana: (a) Ketakutan, hal ini dibuktikan dengan kalimat: "Jangan tinggalkan saya! tolong! tolong! tolong! nyalakan lampu, saya takut gelap, saya takut sendirian". (b) Gelap, hal ini dibuktikan dengan kalimat: "Dua lelaki yang sama duduk di lantai samping kursi besi yang sama tersekelilingi gelap. Gelap sekali." (c) Pengap, hal ini dibuktikan dengan kalimat: "Di sini pengap. Keringat tak henti-hentinya menyembul dari pori-pori kulit." (d) Mencekam, hal ini dibuktikan dengan penggambaran langsung oleh pengarang. Seperti, tokoh Aku atu laki-laki yang seringkali menangis sampai menggerung. Terdapat adegan membunuh yang dilakukan oleh tokoh Aku. Dan perbuatanperbuatan yang di luar kendali manusia lainnya. (e) Sunyi dan sepi, hal ini dibuktikan dengan tokoh Aku atau laki-laki yang sangat butuh teman untuk mengobrol, berbagi rasa, cerita, maupun rahasia karena ia berada seorang diri di dalam sebuah ruangan penjara.

Tokoh dan penokohan dalam drama ini dituangkan dalam Tabel 01 berikut:

Tabel 01. Tokoh dan Penokohan Drama "Cermin"

\begin{tabular}{|l|l|}
\hline \multicolumn{1}{|c|}{ Peran } & \multicolumn{1}{|c|}{ Keterangan } \\
\hline Tokoh Aku atau Laki-laki: & $\begin{array}{l}\text { Merupakan tokoh utama dalam cerita drama. Ia merupakan suami dari } \\
\text { Su, yakni istrinya. Digambarkan dalam cerita drama ia merupakan } \\
\text { sosok laki-laki yang baik, setia dengan pasangannya, dan sabar. }\end{array}$ \\
\hline Sunni atau dipanggil Su: & $\begin{array}{l}\text { Merupakan istri dari tokoh Aku. Digambarkan sebagai seorang } \\
\text { perempuan yang biasa saja namun memiliki daya tarik yang luar biasa. } \\
\text { Su diceritakan sebagai seorang pelacur atau wanita malam. Selain itu, ia } \\
\text { memiliki sifat pemarah, tidak menghargai suaminya, tidak setia, tidak } \\
\text { tahu malu, tidak hormat kepada suaminya. }\end{array}$ \\
\hline orang anak: & $\begin{array}{l}\text { Mereka adalah anak dari tokoh Aku dan Su. Tidak digambarkan dengan } \\
\text { jelas seperti apa ketiga tokoh anak kecil ini, melainkan hanya dengan } \\
\text { pernyataan "Yang sulung entah seperti siapa? Yang kedua entah seperti } \\
\text { siapa dan yang ketiga kulitnya hitam pekat dengan mata yang bulat dan } \\
\text { rambut keriting kecil-kecil." }\end{array}$ \\
\hline $\begin{array}{l}\text { Seseorang berjubah berkerudung } \\
\text { abu-abu: }\end{array}$ & $\begin{array}{l}\text { Pada cerita drama ini, sosok tersebut merupakan pencipta yang tidak } \\
\text { dapat dilihat wajahnya. Melainkan hanya berasal dari imajinasi atau } \\
\text { pemikiran tokoh Aku saja, yang kemudian digambarkan oleh pengarang } \\
\text { melalui ucapan tokoh Aku atau laki-laki tersebut. }\end{array}$ \\
\hline Teman: & $\begin{array}{l}\text { Tokoh ini sebenarnya hanyalah bentuk khayalan dari tokoh Aku. Tidak } \\
\text { benar-benar ada seorang teman yang mengobrol dengannya, melainkan } \\
\text { ia melihat wajahnya sendiri di hadapan sebuah cermin yang kemudian } \\
\text { ia anggap bahwa itu adalah teman. Wujud yang ditampilkan pun tentu } \\
\text { saja ialah tokoh Aku. }\end{array}$ \\
\hline
\end{tabular}

Amanat yang terkandung dalam naskah drama "Cermin" ialah sebagai berikut: (a) Ketika ingin menikah, maka kenalilah pasangan kita dengan baik terlebih dahulu. Mulai dari bibit, bebet, dan bobotnya. Karena kehidupan pernikahan bukanlah sesaat, melainkan ada kehidupan panjang yang 


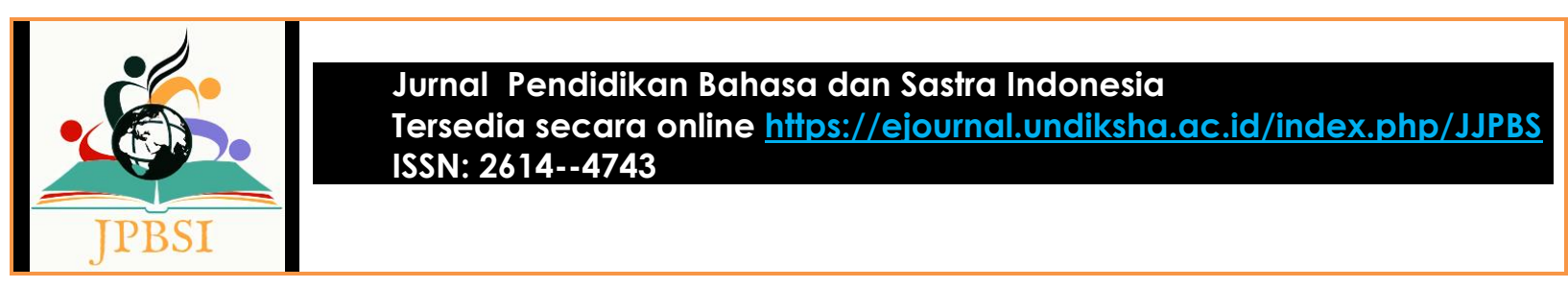

akan ditata dan dihadapi kedepannya. (b) Carilah pekerjaan yang dapat memuliakan kita sebagai seorang manusia. Kerjakan sesuatu yang halal dan bermanfaat. (c) Harus bisa menghargai satu sama lain terlebih dalam suatu hubungan. Dengan begitu, akan terciptanya keharmonisan dan kerukunan. (d) Jika ingin melakukan suatu hal haruslah dipikir dengan baik-baik dan secara matang, agar tidak terjadi penyesalan yang begitu mendalam. Hendaknya dalam sebuah hubungan, perlu menjaga yang namanya komunikasi. Agar sama-sama mengetahui apa yang disukai dan tidak disukai oleh pasangan kita. Selain itu, komunikasi yang baik akan melahirkan rasa percaya dan ketenangan bagi pasangan. Sehingga pasangan tidak mudah cemburu, tidak mudah overthinking, dan mengurangi keributan atau cek-cok dalam sebuah hubungan.

Gaya penulisan yang digunakan ialah dengan gaya bahasa dan sastra baru atau modern. Katakatanya mudah dipahami atau dalam arti lain seperti penggunaan bahasa sehari-sehari. Terdapat penggunaan kata baku dan juga majas di dalamnya. Sehingga menambah nilai seni di dalamnya. Selain itu, gaya bahasa yang tidak berat membuat para pembaca mampu memahami makna yang terdapat dalam cerita drama tersebut.

Dari segi penyusunan peristiwa atau bagian-bagian yang membentuk cerita dari drama "Cermin" menggunakan plot campuran atau alur maju mundur. Pengarang menyajikan ceritanya tidak secara berurut, melainkan dimulai dari klimaks. Setelah itu para pembaca dibawa mundur untuk pengenalan dalam cerita, lalu maju ke awal munculnya konflik, hingga berakhir dipenyelesaian yakni tokoh Aku mati akibat bunuh diri sendiri.

Sudut pandang yang digunakan oleh pengarang cerita drama "Cermin" ini yaitu sudut pandang campuran. Pengarang menempatkan tokoh Laki-laki menjadi sosok 'Aku' sekaligus 'Teman atau kamu' secara bergantian.

\section{Kajian Berdasarkan Tinjauan Psikologis/Kejiwaan Pengarang}

Asumsi dasar penelitian psikologi sastra antara lain dipengaruhi oleh anggapan bahwa karya sastra merupakan produk dari suatu kejiwaan dan pemikiran pengarang yang berada pada situasi setengah sadar (subconcius) setelah jelas baru dituangkan ke dalam bentuk secara sadar (conscius). Pada cerita drama "Cermin" ini, Nano Riantiarno mampu mengungkapkan ekspresi kejiwaannya tentang suatu persoalan kehidupan. Ide maupun imajinasinya ini dituangkan melalui penggambaran tokoh 'Aku' atau 'Laki-laki' yang mencakup semua peranan tokoh. Hal ini ditunjukkan dengan bukti sebagai berikut:

"Jangan!Jangan tinggalkan saya! Tolong! Tolong! Tolong! Nyalakan lampu, saya takut gelap! Saya takut sendirian! Tolong! Jangan tinggalkan saya! Cahaya, saya butuh cahaya! Saya butuh terang! Tolong.... cahaya... cahaya." Dialog yang diucapkan oleh tokoh 'Aku' merupakan bentuk emosional yang digambarkan penulis tentang betapa menakutkannya kehidupan dibalik jeruji besi. Sangat gelap dan sunyi. Membuat tokoh 'Aku' merasa ketakutan dan tak mau sendirian.

"Sampai mati.. Su! Su! Sunni! Kenapa jadi begini? Kenapa kau pergi?kenapa aku ada di sini? Kenapa mesti ada hal-hal yang mendorong kita melakukan hal-hal? Kenapa kamu tidak mau menurut? Kenapa waktu kamu masih ada, rasanya semua terang dan jelas, tanpa kabut. Tiap ku pandangi diriku dikaca, maka kulihat ujud seorang laki-laki yang utuh. Lalu sekarang, kau entah ada di mana? Jarak dan tembok memisahkan kita. Terjadi begitu saja, didorong oleh kekuatan yang ajaib! Seperti air sungai yang dibendung, makin tinggi bendungannya makin banyak air yang tertampung dan tekanan untuk molos mencari aliran lain makin besar. Lalu saat air tak terbendung lagi sedang tekanan makin besar, makin besar. Dan tiba-tiba bendungan jebol!." Pengarang mencoba mengekspresikan bagaimana bentuk amarah yang terjadi pada tokoh 'Aku' saat melakukan perbuatan yang melanggar norma hukum sehingga menimbulkan penyesalan yang teramat mendalam bagi dirinya. 


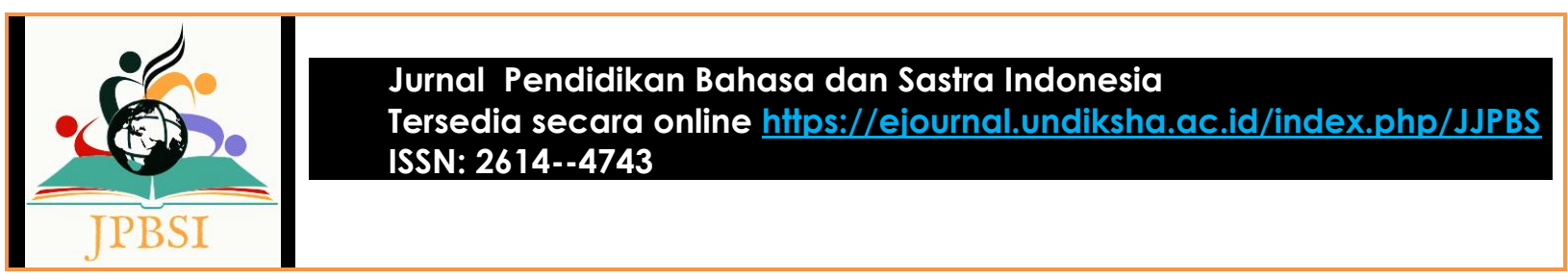

"Dan Sunniii...gemanya! gemanya melengking! Tak tahan aku untuk tidak berbuat apa-apa. Dan bisik-bisik itu. Bisik-bisik yang memerintahkan aku supaya melakukan niatku, musnahkan! Musnahkan hancurkan! Hancurkan biar jadi abu sekalian. Dari abu kembali jadi abu, kata bisik-bisik itu dalam telinga." Pada bagian ini, pengarang menggambarkan suasana yang tidak dapat dikendalikan atau dikontrol akibat memendam amarah yang terlalu lama dan besar. Digambarkan melalui bisikan-bisikan yang mempengaruhi sehingga timbul atau terlaksananya perbuatan keji tersebut.

"Tahukah kamu mengapa aku masih tetap bisa menahan diri selama ini? Masih tetap mendampinginya meski jantung perih bukan main? Karena aku mencintai Su! Karena aku sudah bersumpah untuk tetap setia apapun yang sudah dia lakukan." Rasa kesetiaan, bentuk tanggung jawab, kesabaran sekaligus kebodohan yang digambarkan oleh pengarang terhadap tokoh 'Aku' merupakan bentuk penggambaran yang biasanya terjadi dalam sebuah hubungan. Adanya sumpah atau akad dalam sebuah pernikahan merupakan janji kepada Tuhan, yang mana pada dasarnya sebuah janji haruslah ditepati dan laksanakan. Namun tetap dengan mengutamakan akal pikiran yang sehat.

"Aku butuh ketengan. Aku butuh perempuan yang kucintai dan mencintaiku. Aku butuh perhatian dan diperhatikan. Dan semuanya sudah terjadi akibat dari kau, $O$, kelemahan, besok aku akan dihukum mati. Pertama kali dalam penjara. Sudah kubunuh 6 orang dan melukai 3 orang. Betulkah itu? Sebegitu besarkah tenagaku waktu itu? O, aku tidak tahu." Sebagai lakilaki normal, tentu saja kehadiran wanitanya sangatlah diperlukan. Hal ini berkaitan dengan jiwa, akal sehat, dan juga perilaku yang ingin digambarkan penulis melalui tokoh 'Aku'. Rasa tak percaya akan hal keji yang sudah ia lakukan merupakan bentuk akan kurangnya perhatian, kasih sayang, dan juga cinta dari wanitanya.

"Aku berteriak, suara tidak keluar, aku berteriak dalam hati, tolong aku mau berhenti stopkan! Stopkan! Tolong!!! Aku harus terus dan terus hingga hal itu membuatku gila. Sudah pasti gerakan-gerakan tariku tanpa isi karena sama sekali tidak kugerakkan berdasarkan keinginan hati dan jiwa. Aku teriak-teriak, dalam hati. Berhenti, aku belum mau mampus. Aku kepayahan! Tolong! Tolong! Tolong stopkan! Tapi siapa yang sanggup menolong? Kulihat orang-orang sekelilingku juga melakukan hal yang sama. Menarikan tarian-tarian yang belum tentu ingin mereka lakukan. Dunia penuh dengan manusia yang menarikan gerakan-gerakan yang aneh." Pada kutipan monolog tersebut, pengarang menggambarkan atau mengekspresikan keadaan sosial terutama dalam sebuah lingkungan masyarakat. Banyak dari kita yang melakukan kegiatan atau melakukan suatu hal, tanpa tahu kemana dan apa tujuannya. Seolah ada yang menggerakkan lewat hati dan pikiran manusia itu sendiri. Hal ini berkaitan dengan yang dialami tokoh 'Aku' melalui perumpamaan 'gerakan-gerakan tarian'. Ia tidak ingin hal itu terjadi, namun nyatanya hal itu diluar kendali dan akal sehatnya. Dan hal itu tidak dapat dipungkiri.

Setelah membaca naskah drama 'Cermin', peneliti merasakan kenikmatan-kenikmatan dari pengarang untuk mengetahui lebih lanjut dunia batin pengarang melalui penggambaran tokoh utama 'Aku'. Penggambaran yang dilakukan oleh pengarang dibentuk melalui sebuah monolog, yang mana hanya terdapat satu orang pemain atau lakon pada drama tersebut. Dari satu tokoh tersebut, melalui monolog yang dilakukan terciptalah tokoh-tokoh lain. Dapat dikatakan bahwa tokoh laki-laki ini berperan ganda. Hal ini selaras dengan judul yang diberikan oleh pengarang yakni 'Cermin'. Drama 'Cermin' ini mengisahkan tentang perjalanan kehidupan seorang laki-laki yang akan mengalami hukuman mati setelah peristiwa yang ia lakukan. Semua bermula ketika tokoh laki-laki ini menikahi wanita yang bernama 'Sunni', seorang mantan pelacur. Bahkan ketika mereka sudah menikah, Sunni tetap melakukan pekerjaannya sebagai seorang pelacur. Ia melakukan hal itu bukan atas dasar cinta, melainkan adanya faktor kebutuhan hidup yang harus terpenuhi. Awalnya tokoh laki-laki menerima 


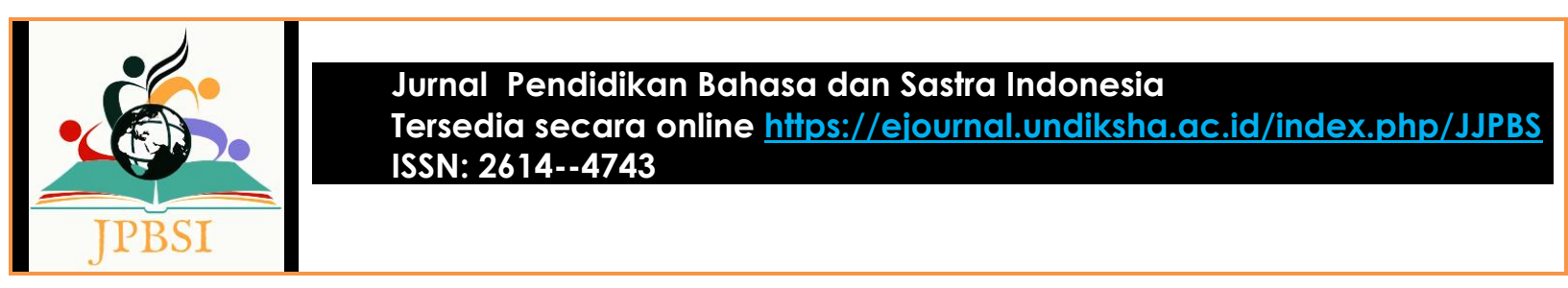

kenyataan yang dilakukan istrinya bahwa ia tidak bisa membahagiakan istrinya, ia hanya mampu memberikan anak, tak mampu berbuat lebih seperti yang dikatakan istrinya kepada dirinya.

Namun disatu sisi, ia juga tidak percaya apakah anak-anak itu merupakan anak kandungnya atau anak dari laki-laki lain. Dari sinilah konflik muncul, ibarat air yang sedang dipanaskan, lama kelamaan suhu itu akan memuncak, begitu pula dengan tokoh laki-laki ini. Akibat perlakuan istrinya yang seperti tidak menganggap dirinya, memperlakukannya seperti bukan manusia, membuat ia geram dan memunculkan rasa marah yang besar hingga terjadinya peristiwa berdarah itu. Sebelumnya telah dilakukan penelitian yang sama dalam menggunakan pendekatan eskpresif untuk mengkaji karya sastra. Salah satunya 'Analisis Drama Balon (Bakal Calon) Karya Suyadi San Dengan Pendekatan Ekspresif' oleh Mira Asni Rizki. Dalam penelitiannya, terdapat hasil analisis gambaran perasaan dan pikiran pengarang yakni rasa senang, marah, bangga, emosi, gelisah, dan sombong. Sedangkan untuk pikiran, terdiri atas pikiran sadar dan tak sadar. Yang mana disimpulkan bahwa perasaan dan pemikiran itu selalu berhubungan dengan ekspresi pengarang yang ditimbulkan melalui tokoh-tokoh drama.

Sedangkan untuk penelitian kali ini, peneliti mencoba mengungkapkan ekspresi pengarang melalui tokoh utama 'Aku'. Pengarang mencoba menempatkan dirinya sebagai tokoh utama yang diperankan sebagai seorang laki-laki. Walaupun dalam kehidupan aslinya, ia tidak mengalami dan merasakan seperti pada cerita drama yang dibuatnya. Karena ini merupakan hasil dari pemikiran, imajinasi, dan berdasarkan fenomena kehidupan yang pengarang temui. Adapun perasaan-perasaan yang dituangkan pengarang melalui tokoh 'Aku' ialah perasaan takut, kesepian, amarah, penyesalan, emosi yang tidak terkendali, kesetiaan, tanggung jawab, kesabaran, kebodohan, kurangnya perhatian dan kasih sayang, serta keadaan sosial dalam lingkungan masyarakat. Rasa takut akan kesepian yang dialami tokoh 'Aku' pada saat tinggal dibalik jeruji besi, merupakan bentuk dari ekspresi pengarang sebagai seorang manusia biasa yang apabila berada di dalam suatu tempat asing, gelap, dan sunyi maka, akan timbul perasaan seperti itu. Terlebih apa yang dihadapinya saat itu merupakan akibat dari kesalahan yang dilakukannya. Kedua, ialah rasa marah dalam KBBI yang bermakna sebagai perasaan tidak senang karena dihina atau diperlakukan tidak sepantasnya. Hal inilah yang ingin digambarkan oleh pengarang sebagai seorang laki-laki melalui tokoh 'Aku'. Tentu, baik laki-laki ataupun perempuan ingin dihormati dan diperlakukan dengan baik oleh orang lain terlebih dengan pasangannya sendiri. Karena sebagai manusia biasa, kita memiliki batas kesabaran. Ketiga, rasa kesetiaan dan tanggung jawab yang ingin digambarkan pengarang melalui tokoh 'Aku' merupakan bentuk dari seorang pria dewasa. Laki-laki ketika berkeluarga nanti, ia akan menjadi suami sekaligus ayah untuk keluarganya. Hal besar yang dapat dibuktikan ialah melalui kesetiaan terhadap istrinya dan bentuk tanggung jawab terhadap keluarganya. Selanjutnya ialah kurangnya perhatian dan kasih sayang, dalam hal ini pengarang mencoba memberitahu, bahwa bukan hanya wanita saja yang ingin diperlakukan istimewa, diberikan perhatian dan juga kasih sayang. Laki-laki pun sama. Mereka memiliki hasrat untuk diperlakukan dengan baik. Karena pada dasarnya laki-laki lebih lemah dalam hal emosional dibandingkan wanita.

\section{PENUTUP}

Berdasarkan hasil penelitian yang telah dipaparkan dapat diambil kesimpulan, yakni terdapat bentuk ekspresif yang dituangkan pengarang melalui tokoh utama 'Aku'. Perasaan-perasaan tersebut ialah perasaan takut, kesepian, amarah, penyesalan, emosi yang tidak terkendali, kesetiaan, tanggung jawab, kesabaran, kebodohan, kurangnya perhatian dan kasih sayang, serta keadaan sosial dalam lingkungan masyarakat. Dalam melakukan analisis karya sastra salah satunya ialah kajian drama dengan menggunakan pendekatan ekspresif, terdapat tiga hal yang menjadi poin penting dalam mengkajinya. Diantaranya ialah sebagai berikut: Ketika menerapkan pendekatan ekspresif, seorang kritikus maupun peneliti harus mengenal biografi pengarang karya sastra yang akan dikaji; 


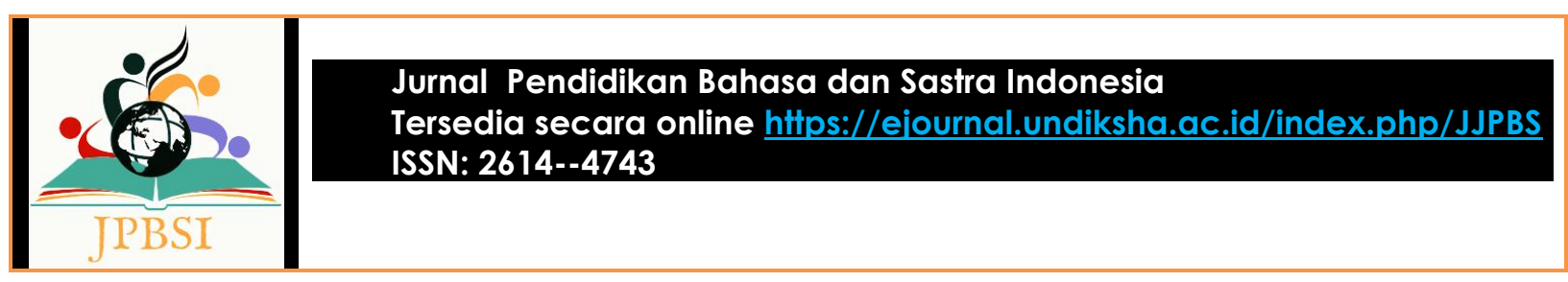

Melakukan penafsiran pemahaman terhadap unsur-unsur yang terdapat dalam karya satsra, seperti tema, gaya bahasa/diksi, alur/plot, amanat, citraan, dan lain sebagainya; Mengaitkan hasil penafsiran tersebut dengan berdasarkan tinjauan psikologis atau kejiwaan pengarang. Karena pada dasarnya, pendekatan ekspresif merupakan bentuk imajinasi, ide, ataupun pemikiran pengarang yang berusaha menggambarkan sebuah cerita berdasarkan pengalaman maupun kejadian yang memang dialami sendiri oleh pengarang. Selain itu, dalam melakukan analisis pendekatan ekspresif tidak hanya melalui imajinasi pengarang, melainkan unsur-unsur yang menjadi pembangun sebuah cerita juga termasuk ke dalamnya. Hal ini dikarenakan unsur instrinsik dan unsur ekstrinsik merupakan satu kesatuan yang saling berkaitan untuk menyempurnakan sebuah karya sastra. Dengan adanya kedua unsur tersebut, dapat menghidupkan cerita dan membuatnya lebih tersusun secara baik. Dalam arti lain, pendekatan ekspresif tidak hanya pada ruang lingkup sebatas pengarang saja, namun hal-hal yang berkaitan dengan karya sastra dan latar belakang pengarang juga termasuk ke dalam bagiannya.

\section{DAFTAR PUSTAKA}

Adiarini, Septyandary Sukma. (2017). Pendekatan Ekspresif Posisi Perempuan Dalam Drama Waktu Perempuan Karya Royal Ikmal. Sumbawa: Penerbit Pelajar Bahasa.

Al Anshori, Ubai Dillah. (2017). Analisis Cerpen Lelaki Ragi Dan Perempuan Santan Karya Damhuri Muhammad Dengan Pendekatan Ekspresif. Padang Panjang: Unimed.

Ariyani, Retno. (2020). Analisis Tokoh Naskah Drama "Bapak" Karya Bambang Soelarto. Yogyakarta: Penerbit Repository, 26-40.

Armanda, Arie. (2018). Analisis Cerpen Kaki Yang Ajaib Karya Hasan Al Banna Dengan Pendekatan Ekspresif. Medan: Penerbit Core.

Furqon, MA. (2013). Bab 3 Metode Penelitian. Surabaya: Digilib Uinsby, 62-65.

Miftahun, Munidi. (2012). Cermin Karya Nano Riantiarno. Jakarta: Penerbit Wordpress.

Nandani, Rikha. (2015). Kajian Ekspresif Naskah Digugu dan Ditiru. Wordpress. https://teaterzat.wordpress.com/2015/03/03/kajian-ekspresif-naskah-digugu-dan-ditiru/.

Pengertian Drama. (2011). Hangkah https://winawimala.wordpress.com/2011/03/24/pengertian-drama/.

Rizki, Mira Asni. (2017). Analisis Drama Balon (Bakal Calon) Karya Suyadi San Dengan Pendekatan Ekspresif. Medan: Repository UMSU, 6-22.

Sugiarto, Sri. (2010). Pendekatan Ekspresif Dalam Apresiasi Sastra. Pelajar Bahasa. http://ssgpelajarbahasa.blogspot.com/2011/11/pendekatan-ekspresif.html?m=1.

Copyright holder: @ Salsabila, N. \& Devi, W. K. (2021)

Fist publication right: Jurnal Pendidikan Bahasa dan Sastra Indonesia Undiksha

(c) (i) (2) 